\title{
PSYCHE
}

VOL. XLI

JUNE 1934

No. 2

\section{THE ORIGIN OF THE PERITROPHIC MEMBRANE IN SCIARA AND THE HONEY BEE}

\author{
By F. H. ButT \\ Cornell University.
}

Many explanations have been given for the origin of the peritrophic membrane. Some authors maintain that it is formed from secretions of the epithelial cells of the mid-intestine and is non-chitinous in structure. Others think it is a continuation of the chitinous intima lining the œsophagus and is secreted by cells lying at the junction of the fore and mid-intestine. No investigation has been made of its origin in the embryo.*

Recently while making an embryological study of Sciara I was interested in the extreme length attained by the stomodæal membrane in the later stages. It so resembled the peritrophic membrane of the larva both in its position and in its point of attachment that a relationship between the two was immediately evident. Therefore a number of newly emerged larvæ were killed and sections were made to see if a peritrophic membrane were present in the very first stage, and if so, whether it had any resemblance to the stomodæal membrane in the embryo. The larvæ were fixed in Carnoy-LeBrun fluid for thirty seconds and were embedded in rubber-paraffin. The sections were cut at four microns, were stained in magenta and counter-stained in picro-acid-carmine.

\footnotetext{
* Since this paper was submitted for publication, a paper by Gambrell has appeared (Ann. Ent. Soc. Am. Vol. XXVI:641) mentioning the origin of the peritrophic membrane in Simulium.
} 
In the embryo, the stomodæum begins as a shallow depression in the ectoderm at the anterior end shortly after the thirtieth hour, coincident with the beginning of segmentation. As it deepens, it forms a tube closed at its inner end by ectodermal cells (fig. 1). These cells become thinner as the end of the tube widens until at the sixty-fifth hour the tube is closed at its inner end by a thin membrane in which no nuclei are present. Between the sixty-fifth and the seventieth hours the end of the stomodæum flattens and spreads out. At the same time the stomodæal membrane increases in size and hangs loosely in the yolk. The stomodæum now resembles an inverted hollow mushroom, the membrane forming the outline of the cap (fig. 2). As the stomodæum continues to grow, the flattened end folds back on itself so that the mesodermal layer (m) surrounding the stomodæum lies between two layers of ectoderm (fig. 3).

The stomodæal membrane hangs loosely in the yolk and steadily increases in size, not as the result of cell proliferation but apparently by secretions from differentiated cells located on the end of the recurved stomodæum where it joins the mid-intestine (fig. 2 , stom $\mathrm{m} \mathrm{c}$ ). These cells are elongated, with their extremities drawn out very thin where the substance of the stomodæal membrane is given off. At the eightieth hour only a few secretory cells are to be seen. They increase in size and in number between the eightieth and ninetieth hours until they form a very conspicuous mass around the stomodæum (fig. 3 ). In the meantime the membrane (stom $\mathrm{m}$ ) has lengthened. The muscular wall of the fore-intestine, lying between the two layers of ectoderm of the stomodæum, is still thin. Figure three represents the stomodæum at ninety hours, shortly before the larva emerges from the egg. The walls of the mid-intestine at this time are complete.

Between the ninetieth hour in the egg, and the time the hatched larva is ready to feed, the appearance of the stomodæum changes considerably (fig. 4). The sack-like stomodæal membrane becomes the tube-shaped peritrophic mem- 
Psyche, 1934

Vol. 41, Plate 4

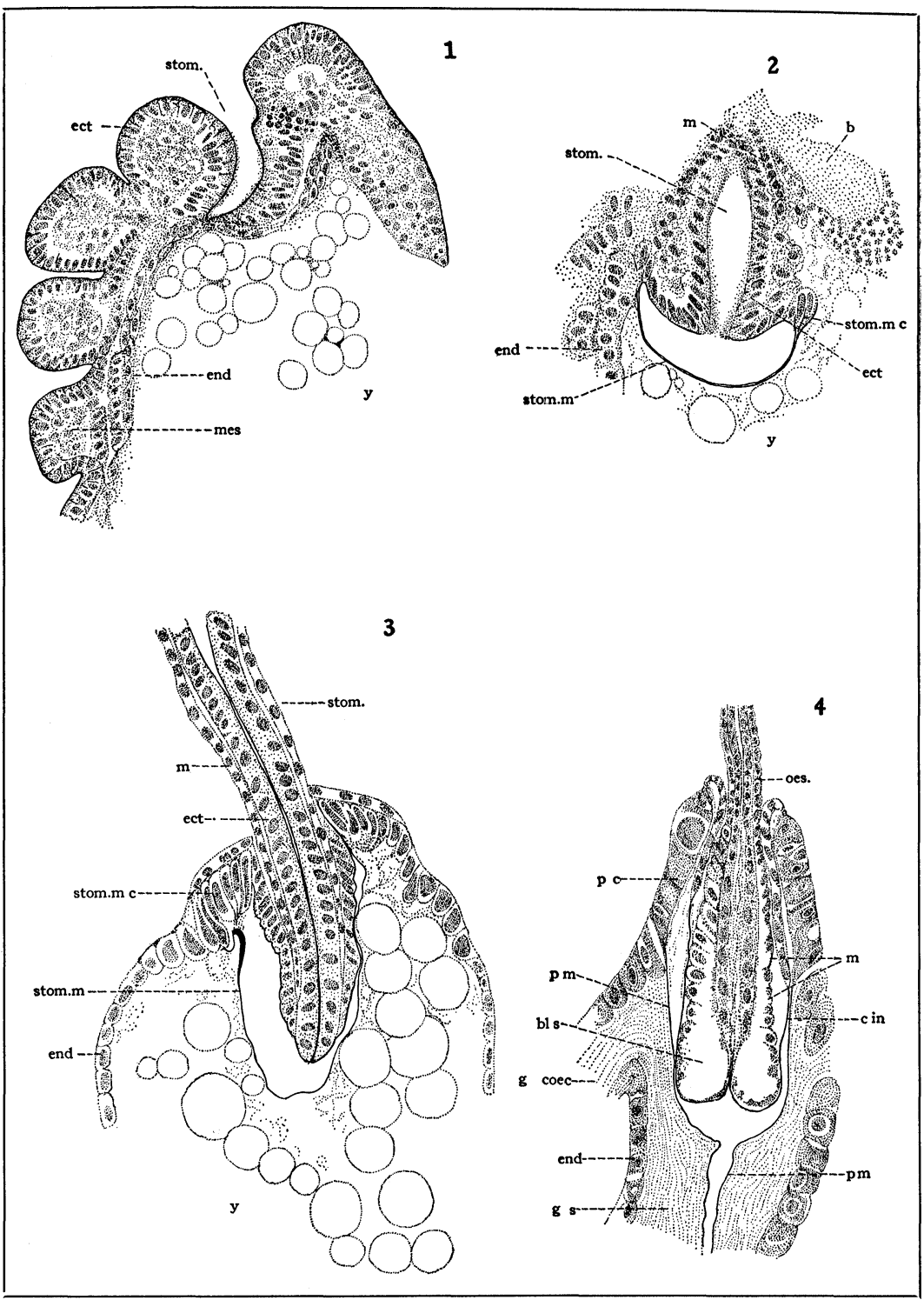

Butt-Peritrophic Membrane in Sciara 
brane probably when the first food breaks through the sack on its passage down the intestine. The muscular wall $(\mathrm{m})$ of the csophagus (oes) that was a simple layer of cells at the ninetieth hour (fig. 3 ), expands into a bulb-like ring at the end of the cosophageal valve. Inside this ring is an open space which Wigglesworth (30) calls a blood sinus (bl s). This muscle with its blood sinus is a sphincter which, when expanded, closes off the mid-intestine to the entrance of food. When contracted, the passageway through the œsophageal valve is open. The ectodermal cells, lining the stomodæum, that were so large in the embryo, have thinned out and disappeared over the end of the bulbous ring, their place being taken by a thin membrane, the chitinous intima (c in). The cells secreting the peritrophic membrane ( $p$ c) which have now assumed a very regular appearance with smooth inner and outer walls, are very large and vacuolated. At the sides of the mid-intestine lie the two gastric cœca (coec) which discharge their contents into the intestine near the œsophageal valve. Their contents are prevented from bathing the œsophageal valve by the peritrophic membrane $(\mathrm{m})$ which is forced together by the fluid and extends down into the mid-gut.

Nelson ('15) states that the stomodæum in the honey-bee is closed at its inner end by cells of the anterior mesenteron rudiment. He does not mention any embryonic origin for the peritrophic membrane. Snodgrass ('25) refers to Nelson in regard to the stomodæal membrane and says, "the old idea that the peritrophic membrane of insects is a backward prolongation of the chitinous intima of the proventriculus has been discredited in all recent investigations on its origin." He finds that it is formed in the adult bee from protoplasmic bodies given off from the epithelial cells of the mid-intestine. These fill in the granular layer. Wigglesworth ('30) is of the opinion that the peritrophic membrane is of two-fold origin: a chitinous basis, secreted at the anterior end of the mid-gut and a series of indefinite membranes which condense on the outside of this as it proceeds down the gut. Having access to some slides of the 
honey-bee embryo, I was interested to see if there were any possible embryonic fore-runners of the peritrophic membrane.

An examination of the slides indicated that the stomodæal invagination forms in the same manner as in Sciara. The cells in the floor of the invagination are a continuation of the ectoderm which forms the walls of the tube. The tube lengthens and widens at the end, the floor being reduced to a thin membrane similar to that described above for Sciara. Late in the embryonic stage the inner walls of the stomodæum protrude into the mid-intestine rupturing the membrane. Around this invaginating tube lies a thickened ring of cells that resembles the ring of cells secreting the stomodæal membrane in Sciara. It also corresponds to the basal folds of the mid-gut as figured by Wigglesworth ('30) from which, he says, originates part of the peritrophic membrane. Campbell ('29) has demonstrated the presence of chitin in the peritrophic membrane which is further proof that it arises from the ectoderm. A study of the first stage larva would undoubtedly yield more evidence but no larvæ were available at the time this study was being made.

\section{Summary}

An examination of the esophageal valve in both the embryological and the early larval stages of Sciara indicates that the peritrophic membrane is a continuation of the stomodæal membrane and is ectodermal in origin. It arises from a group of large secretory cells lying around the osophageal valve and attached to the upper edge of the midintestine. These cells which are also ectodermal in origin, begin their development from the end of the stomodæum as it widens out and reverses its direction of growth. The large bulbous muscular layer of the œsophagus which encloses the blood sinus, develops from the single layer of mesoderm which surrounds the stomodæum.

In the honey-bee the formation of the stomodæum resembles the development in Sciara except that the stomodæal membrane does not attain such a great length but is 
broken when the inner end of the stomodæum pushes through. The peritrophic membrane, as described by Wigglesworth, is chitinous and arises from a mass of cells corresponding in position to the base of the stomodæum in the embryo. This indicates that the peritrophic membrane is ectodermal in origin.

\section{Literature Cited}

Campbell, F. L. 1929. The detection and estimation of insect chitin; and the irrelation of chitinization to hardness and pigmentation of the cuticula of the American cockroach, Periplaneta americana L., Ann. Ent. Soc. Am., Vol. 22, pp. 401-426.

Nelson, J. A. 1915. The embryology of the honey-bee, Princeton University Press, pp. 1-282.

Snodgrass, R. E. 1925. Anatomy and physiology of the honey-bee. McGraw Hill Book Co., New York, pp. $1-327$.

Wigglesworth, V. B. 1930. The information of the peritrophic membrane in insects with special reference to the larvae of mosquitoes. Quart. Jour. Mirc. Sc., Vol. 73, Part IV, pp. 593-616. 

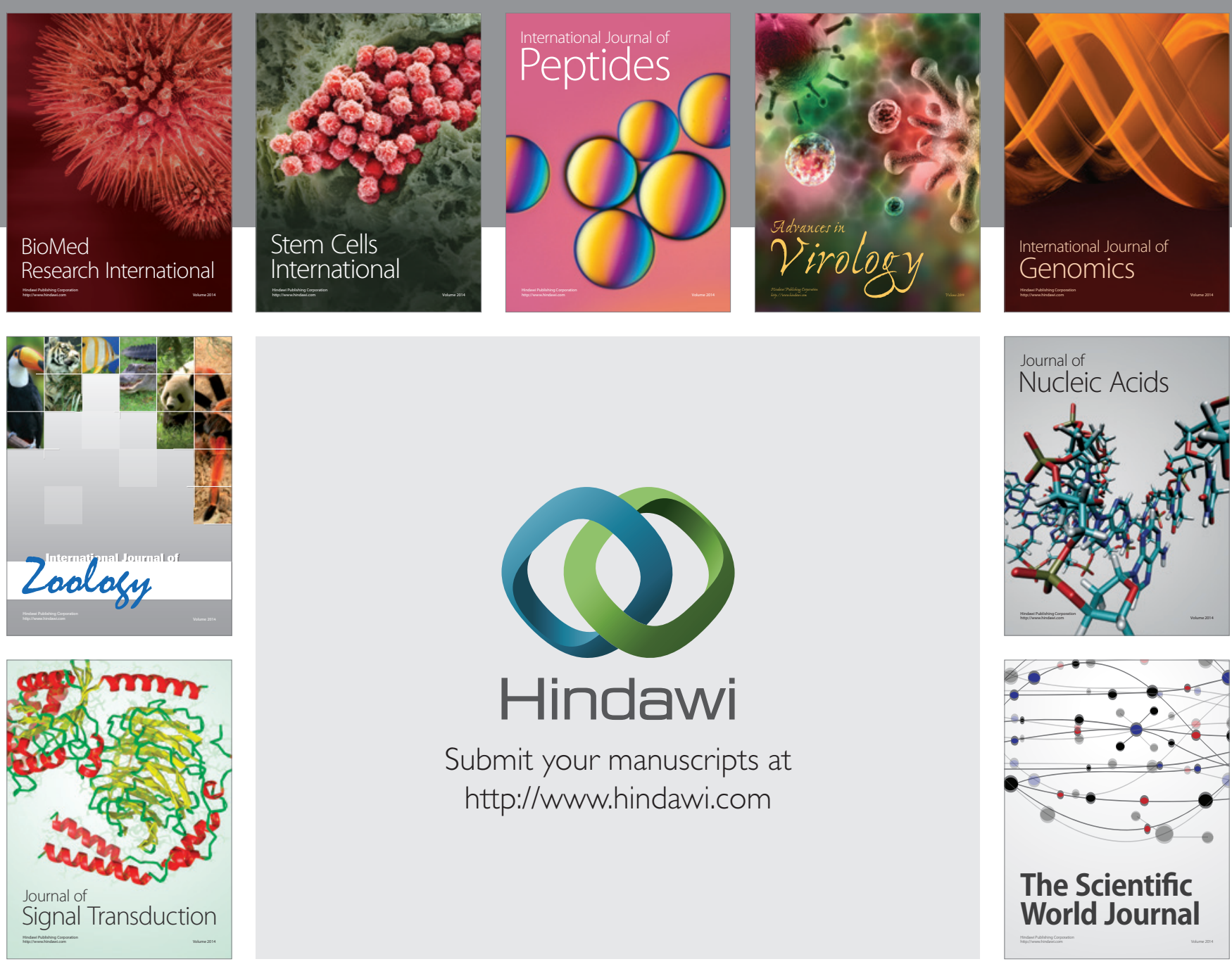

Submit your manuscripts at

http://www.hindawi.com
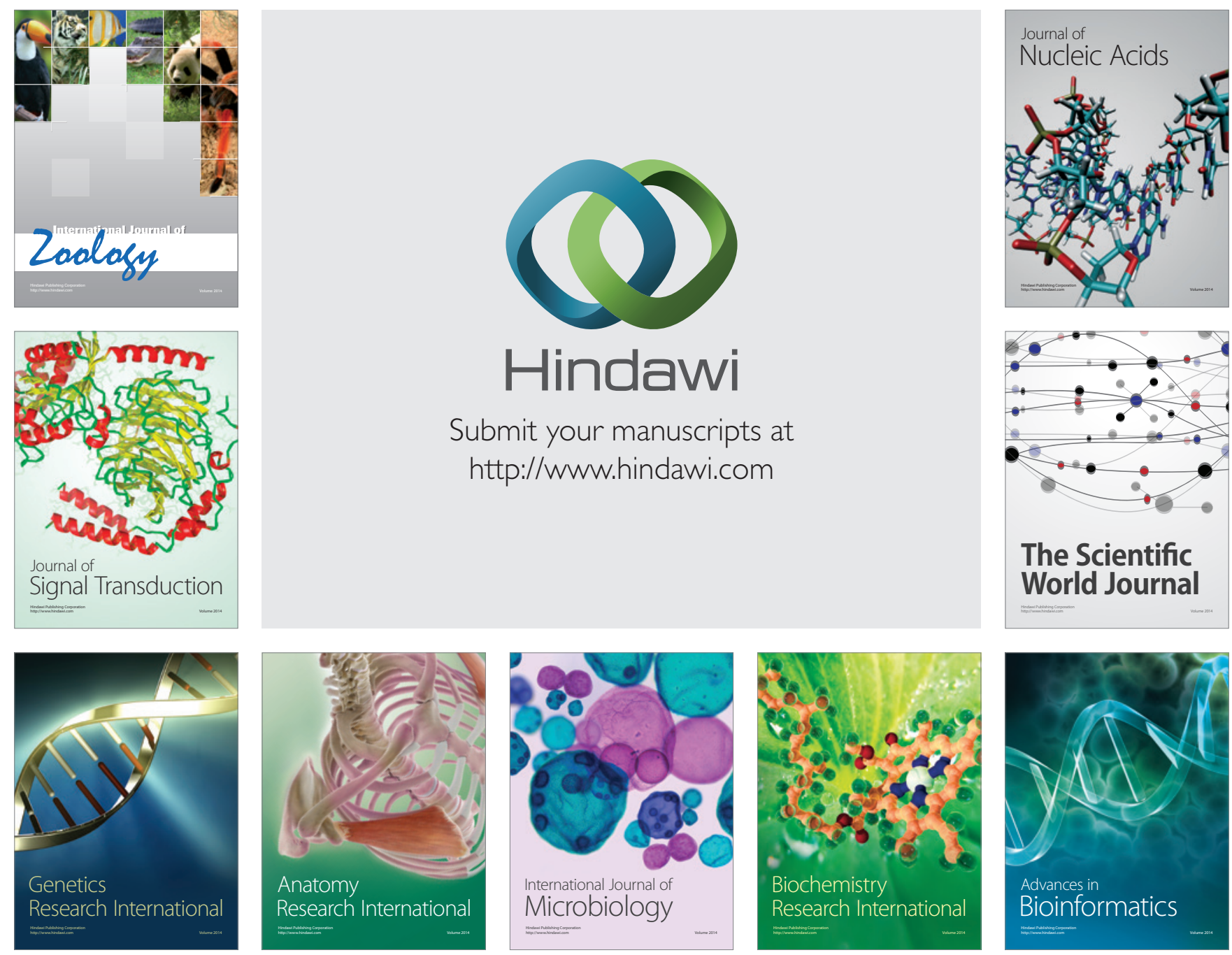

The Scientific World Journal
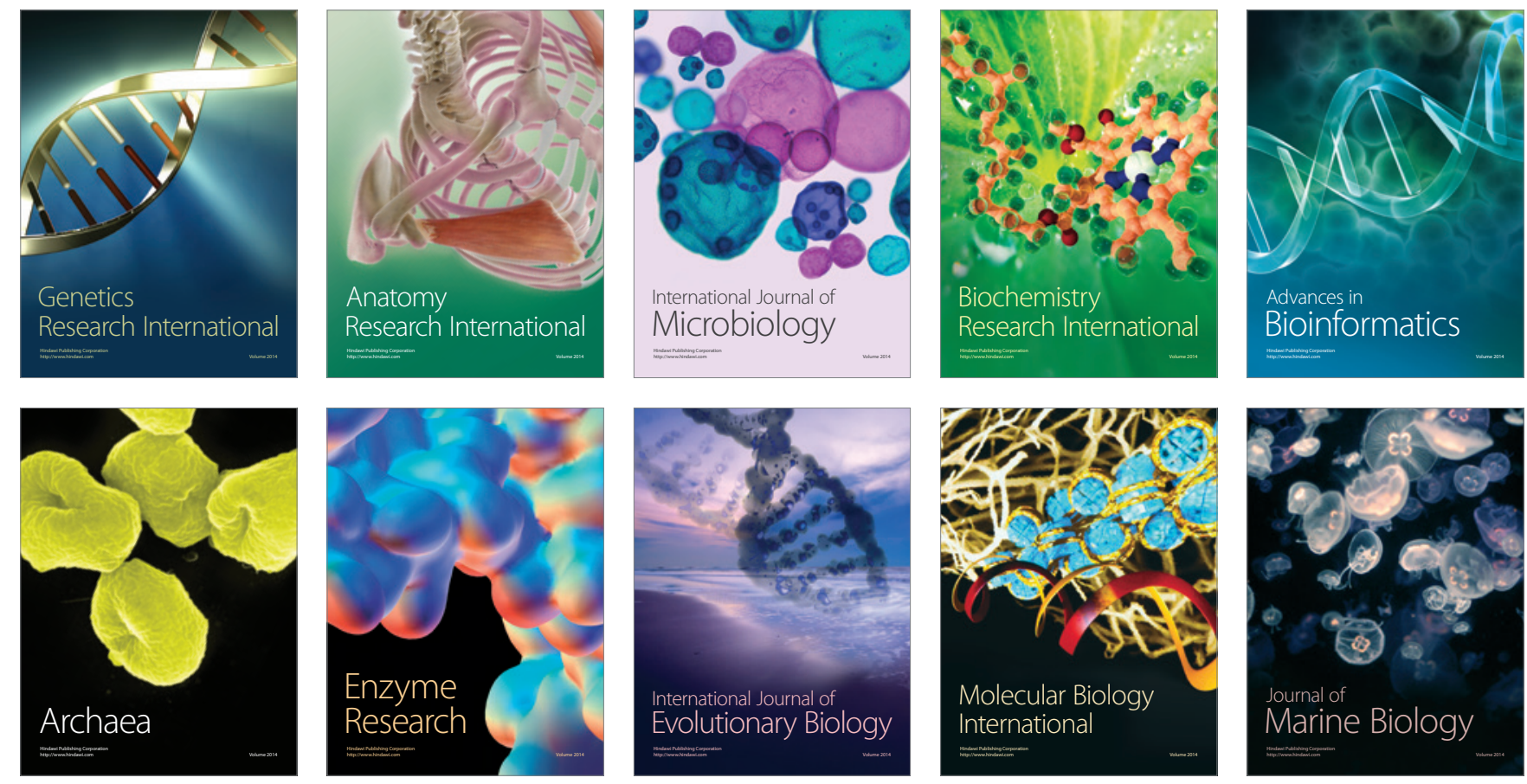